\title{
Impact of Information and Communications Technology Integration on Electrical Installation and Maintenance Work Trade Teachers in Technical Colleges of Kano State, Nigeria
}

\author{
${\text { Dauda } \text { Moses }^{1 *} \text {, Mujittapha Idris Wawo }}^{2}$, Isaac John Ibanga ${ }^{1}$, Isah Muhammad Musa ${ }^{3}$ \\ ${ }^{I}$ Department of Electrical Technology Education, Modibbo Adama University of Technology, Yola \\ Adamawa Stat, Nigeria \\ ${ }^{2}$ Department of Electrical Engineering, School of Technology, Kano State Polytechnic, Kano, Nigeria \\ ${ }^{3}$ Department of Electrical/Electronics Technology, Federal College of Education (Technical), Gombe, \\ Gombe State, Nigeria
}

\begin{tabular}{|c|c|}
\hline Article Info & Abstract \\
\hline \multirow{4}{*}{$\begin{array}{l}\text { Article history: } \\
\text { Received: } 18 \text { May } 2021 \\
\text { Revised: } 21 \text { July } 2021 \\
\text { Accepted: } 22 \text { July } 2021\end{array}$} & Purpose: The main purpose of this study is to assess the impact of ICT \\
\hline & integration on Electrical Installation and Maintenance work trade teachers \\
\hline & in technical colleges in Kano state, Nigeria. \\
\hline & Approach/Methodology/Design: Descriptive survey research design was \\
\hline \multirow{4}{*}{$\begin{array}{l}\text { Keywords: } \\
\text { Impact, } \\
\text { ICT, } \\
\text { Integration, } \\
\text { Electrical Installation, } \\
\text { Technical Colleges }\end{array}$} & adopted for the study. The population of the study was 57 which consisted of \\
\hline & $\begin{array}{l}26 \text { experienced } 31 \text { inexperienced teachers of Electrical Installation and } \\
\text { Maintenance Works Trade. No sampling technique was employed as the }\end{array}$ \\
\hline & entire population was used. The instrument used for data collection was a \\
\hline & $\begin{array}{l}\text { structured questionnaire titled: Impact of ICT Integration on Electrical } \\
\text { Installation and Maintenance Work Trade Questionnaire (IICTIEIMWTQ) }\end{array}$ \\
\hline \multirow{2}{*}{$\begin{array}{l}\text { Paper Type : } \\
\text { Research Article }\end{array}$} & developed by the researchers. The instrument was validated by three experts \\
\hline & and a reliability coefficient of 0.89 was obtained using Cronbach's Alpha \\
\hline \multirow{10}{*}{$\begin{array}{l}\text { Corresponding Author: } \\
\text { Melody Matsvange } \\
\text { Email: } \\
\text { mulkidon1@gmail.com; } \\
\text { mulkidon1@ mautech.edu.ng }\end{array}$} & $\begin{array}{l}\text { research questions, while z-test was used to test the null hypotheses at } 0.05 \\
\text { level of significance. }\end{array}$ \\
\hline & Findings: The finding of the study revealed that the level of ICT integration \\
\hline & in teaching electrical installation and maintenance trade is low; the impact \\
\hline & $\begin{array}{l}\text { of ICT on the performance of electrical installation and maintenance trade } \\
\text { teachers indicated negative impact. }\end{array}$ \\
\hline & Practical Implications: The study has practical implications for teachers. \\
\hline & Based on the findings, Electrical Installation and Maintenance Work Trade \\
\hline & Teachers should engage themselves in group discussion and idea sharing \\
\hline & among them on improving ICT integration in teaching electrical installation \\
\hline & and maintenance trade among others. \\
\hline & $\begin{array}{l}\text { Originality/value: The performance of ICT users will improve as there are } \\
\text { several platforms available for the ICT. }\end{array}$ \\
\hline
\end{tabular}

\section{Introduction}

Electrical Installation and Maintenance work (EIMW) trade programme is aimed at producing craftsmen, technicians, and other skilled personnel who will be enterprising and self-reliant with skills in domestic and industrial installation, as well as operate, maintain and repair electrical and electronic equipment, among others. The trade, as offered in the technical college 
comprises Electrical Installation and Maintenance Work; Instrument Mechanics; as well as Appliance Maintenance and Repairs (Ohikhiare, 2009). These content areas are made up of various tasks involving numerous skills which can be taught and learned in the traditional classroom, laboratory/workshop, or with the use of appropriate technologies (Alegbemi, 2010). As new technologies keep revolving, it becomes imperative for the integration of Information and Communications Technology (ICT) in the teaching and learning of EIMW trade.

Information and communications technology is an umbrella term that includes any communication devices, encompassing radio, television, cell phones, computer and network hardware, satellite systems and so on, as well as their various services such as video conferencing and distance learning. ICT refers to devices that facilitate transmission of information (Musa \& Kanya, 2014). ICT comprise of any electronic device that serves as a means and methods of processing information for different purpose. It encompasses a complex and heterogeneous set of applications and services used to produce, distribute process and transform information. The ICT sector consists of segments as diverse as telecommunications, television and radio broadcasting, computer hardware and software, computer services and electronic media (e.g., the Internet, electronic mail, electronic commerce and computer games) as well as the content of these media.

By integrating ICT into the classrooms, teachers have the ability to engage students to learn more effectively, collaborate with each other, and explore the world around them. Anytime, anywhere access to internet-based tools is necessary to encourage learning inside the classroom and beyond (Gidadawa \& Dogondaji, 2014). Moreover, ICT empowers teachers to engage in the learning process and give them an interest in their job. Furthermore, ICT helps the teacher in behavior management through better tracking of students. It helps not only in the understanding of the students but also in analytical skills which include improvements in reading, comprehension as well as knowledge. ICT unknowingly helps teachers improve in their development of writing skills such as spelling, punctuation, editing and grammar; teachers can become more fluent and original in their work (Ali, Haolader \& Muhammad 2013).

Knowing fully the impact of ICT literacy in education, a policy was introduced by Kano State government to include ICT specifically in the education system. The policy was guided by a document titled "Kano State Revised Education Strategic Plan, (ESP) 2009-2018". It is saddled with the responsibility of identifying sources of serious concern within the educational sector that needs government intervention in terms of ICT facilities and training. However, the specific objectives of the ESP program among others, include: promoting information and communication technology ICT in schools and institutions, gradual expansion of ICT facilities in schools and tertiary institutions, and undertake a needs assessment and feasibility study to provide ICT infrastructure in schools/institutions.

ICT has become an indispensable part to mankind as it has been proven to have impacted positively on the survival and functionality of businesses, economy, social life and meeting the information needs of modern society as well as the progress of the educational sector of 
any nation (Aduwa-Ogiegbaen \& Iyamu, 2015). Balasubramanian et al. (2019) stated that the application of ICT in education (Electrical Installation and Maintenance Work Trade inclusive) improves the quantity of education and its quality as well. This assertion is in tandem with the view of Yushau and Nannim (2018) who reported that ICT facilitates and enhances teaching and learning; eliminating the obstacles of time and space in teaching and learning. ICT also creates room for inventive, informed and logical thinking, greater output, effectiveness, and informative results (Adeosun, 2010). This is not far from the view of Jung (2015) that ICT enhances both the method of learning and behavioral objectives as well as predicting the outcomes of teaching and learning as well as teachers' productivity in institutions of learning. According to Basil (2020), this is why the knowledge of ICT is very important for technical teachers as they are the implementers of the goals and objectives of education.

Youssef and Dahmani (2018) harangued that using ICT enhances personalized and flexible learning by shifting learning process from the teacher to the students which thus, facilitate and adjust the classroom, educational institutions, communities and systems. It also accelerates the knowledge acquisition of learners, improves learners`skills, increases social mobility, empowers citizens to participate in global economy, and as a result, play a major role in improving the education structure (UNESCO, 2014). It was recommended by Bakare and Olaniyi (2017) that, education sector in Nigeria should holistically encourage the use of innovative and modern technology in order to enhance teaching and learning that will enable the students equip themselves for an ideal world and a challenging environment. Particularly, technology integration in Kano State's Technical Colleges must be adopted to support curricular goals of quality education. This of course to the researchers is essential for proper use of ICT integration since it facilitates the acquisition of necessary skills needed by teacher and students in Technical Colleges especially Electrical Installation and Maintenance Work Trade teachers for survival in this modern age and sophisticated economy.

The contribution of ICT in our daily activities is inevitable, especially in the areas of teaching and learning. It is widely acknowledged that ICT tools can be used to improve the quality of teaching and learning of technical and vocational education. The emergence of ICT has affected TVE in its entirety: in contents, method of teaching and learning, medium of instruction, and training facilities. However, the integration of all these affected areas with ICT in developing country like Nigeria to conform to the realities of the modern time, pose a challenge. In its effort to make ICT part of education, Kano state government in its program "Education Strategic Plan (ESP)" provided ICT infrastructure in schools/institutions, trained teachers on ICT proficiency, and developed a comprehensive plan for gradual expansion of ICT facilities using a phased approach to technical colleges. Considering the role of ICT in education and government effort in introducing ICT into the educational system, the researchers find it imperative and relevant to carry out a study to assess the impact of ICT integration on Electrical Installation and Maintenance work-trade teachers in technical colleges in Kano state, Nigeria.

The main purpose of this study is to assess the impact of ICT integration on Electrical Installation and Maintenance work trade teachers in technical colleges in Kano state, Nigeria. In order to guide the study, the following research questions were answered: 
1. To what level is ICT Integrated in Teaching of electrical installation and maintenance work trade in technical colleges in Kano State?

2. What is the impact of ICT skills on the performance of electrical installation and maintenance work trade teachers in Technical Colleges in Kano state?

The following null hypotheses were formulated and tested at 0.05 level of significance:

1. There is no significance difference between the mean responses of electrical installation and maintenance work trade experienced teachers and inexperienced teachers on the level of ICT integration in teaching electrical installation and maintenance work trade in technical colleges in Kano state.

2. There is no significance difference between the mean responses of electrical installation and maintenance work trade experienced teachers and inexperienced teachers on the impact of ICT skills on the performance electrical installation and maintenance work trade teachers in Technical Colleges in Kano state

\section{Methodology and Procedures}

This study employed a descriptive survey research design and was conducted in Kano State of Nigeria. The geographical location of Kano State is between the latitude $11^{\circ} 599^{\prime} 47^{\prime}$ ' $\mathrm{N}$ and longitude $8^{\circ} 31^{\prime} 0^{\prime}$ 'E of the Greenwich Meridian (World Atlas Map, 2015). Kano State borders Katsina State to the north-west, Jigawa State north-east, Bauchi State to the southeast and Kaduna State to the south-west. The population of the study was 57 which consisted of 26 experienced 31 inexperienced teachers of Electrical Installation and Maintenance Works Trade. No sampling technique was employed as the entire population was used. The instrument for data collection was a structured questionnaire developed by the researchers titled: 'Impact of ICT Integration on Electrical Installation and Maintenance Work Trade Questionnaire (IICTIEIMWTQ)'. The instrument consisted of two parts. Part I dealt with the level of ICT Integration in the teaching of electrical installation and maintenance work-trade; while Part dealt with the impact of ICT skills on the performance of electrical installation and maintenance work trade. Part I and II were treated on a five-point rating and Likert scale, as follows: Very High (VH)/ Strongly Agreed $(\mathrm{SA})=5$, High $(\mathrm{H}) / \operatorname{Agreed}(\mathrm{A})=4$, Moderately High $(\mathrm{MH}) /$ Undecided $(\mathrm{U})=3$, Low $(\mathrm{L}) /$ Disagreed $(\mathrm{D})=2$, Very Low $(\mathrm{VL}) /$ Strongly Disagreed $(\mathrm{SD})=1$

The instrument was validated by three experts from the Department of Electrical Technology Education, Modibbo Adama University of Technology, Yola, Adamawa State. The reliability of the instrument was obtained by administering the questionnaire to 8 electrical installation and maintenance work-trade teachers from Government Technical College Ringim and Government Technical College Hadejia, both in Jigawa State. The reliability coefficient of the instrument was found to be 0.89 . Copies of the instrument were distributed to the respondents and retrieved with the help of two research assistants. The two research questions were answered using mean and standard deviation while the null hypotheses were tested using z-test at 0.05 level of significance. The decision rule for the research questions was based on the real limits of numbers. For the test of hypotheses, when Z-calculated value 
is greater than Z-critical value, the null hypothesis was rejected and if otherwise accepted.

\section{Results and Discussion}

\section{Level is ICT Integration in Teaching of Electrical Installation and Maintenance Work Trade in Technical Colleges in Kano State}

Table 1: Mean rating and Standard Deviation of Opinion of the Respondents Level of ICT Integration in Teaching of Electrical Installation and Maintenance Work Trade

\begin{tabular}{|c|c|c|c|c|c|c|c|c|}
\hline \multirow[t]{3}{*}{$\mathbf{S} / \mathbf{N}$} & \multirow[t]{3}{*}{ Items } & \multirow{2}{*}{\multicolumn{2}{|c|}{$\begin{array}{l}\mathrm{N}_{1}=26 \\
\bar{X}_{1}\end{array}$}} & \multicolumn{4}{|c|}{$\mathbf{N}_{2}=31$} & \multirow[t]{3}{*}{ Remarks } \\
\hline & & & & $\bar{X}_{2}$ & & $\bar{X}_{\mathbf{G}}$ & $\sigma_{G}$ & \\
\hline & & $\sigma_{1}$ & & $\sigma_{2}$ & & & & \\
\hline & $\begin{array}{l}\text { Use of Interactive whiteboard in lesson } \\
\text { delivery }\end{array}$ & 2.88 & 1.34 & 2.77 & 1.56 & 2.82 & 1.46 & Low \\
\hline & Use of internet to search for teaching material & 4.04 & 1.02 & 3.48 & 1.50 & 3.74 & 1.28 & High \\
\hline & $\begin{array}{l}\text { Use of Chat and social network to } \\
\text { communicate with students. }\end{array}$ & 2.81 & 1.36 & 2.77 & 1.36 & 2.79 & 1.36 & Low \\
\hline & Use of MS excel to compute students result & 4.00 & 1.21 & 4.10 & 1.23 & 4.05 & 1.22 & High \\
\hline & $\begin{array}{l}\text { Use of ICT to monitor and evaluate students' } \\
\text { progress or performance }\end{array}$ & 3.88 & 1.34 & 3.39 & 1.52 & 3.61 & 1.44 & High \\
\hline & $\begin{array}{l}\text { Use of power point presentation to } \\
\text { presentation lesson }\end{array}$ & 2.62 & 1.33 & 2.84 & 1.27 & 2.74 & 1.30 & Low \\
\hline & $\begin{array}{l}\text { Use of ICT to provide and prepare online } \\
\text { work or Assignment }\end{array}$ & 3.19 & 1.36 & 2.32 & 1.25 & 2.72 & 1.30 & Low \\
\hline & $\begin{array}{l}\text { Use of computer based test for students } \\
\text { assessment }\end{array}$ & 2.31 & 1.59 & 2.42 & 1.41 & 2.37 & 1.49 & Low \\
\hline & Use of video conferencing to deliver lesson & 2.54 & 1.34 & 2.00 & 1.24 & 2.25 & 1.29 & Low \\
\hline & Use of emails to get feedback from students & 2.65 & 1.17 & 2.65 & 1.38 & 2.65 & 1.28 & Low \\
\hline & use of fax for teacher/students interaction & 2.38 & 1.6 & 1.81 & 1.03 & 2.07 & 1.29 & Low \\
\hline & $\begin{array}{l}\text { use of multimedia for class management and } \\
\text { control }\end{array}$ & 3.19 & 1.3 & 2.52 & 1.32 & 2.83 & 1.31 & Low \\
\hline & use of email to assign classwork/homework & 3.62 & 1.21 & 2.35 & 1.21 & 2.93 & 1.21 & Low \\
\hline & $\begin{array}{l}\text { use of MS word to prepare lesson plan and } \\
\text { lesson note }\end{array}$ & 3.42 & 1.31 & 3.13 & 1.31 & 3.26 & 1.31 & Low \\
\hline & Grand Mean & & & & & 2.92 & 1.32 & Low \\
\hline
\end{tabular}

Key: $\overline{\boldsymbol{X}}_{1}=$ mean response of electrical installation and maintenance trade experienced teachers, $\overline{\boldsymbol{X}}_{2}=$ mean response of electrical installation and maintenance trade inexperienced teachers $\overline{\boldsymbol{X}}_{\boldsymbol{G}}=$ Grand mean of items, $\sigma=$ standard deviation, $N_{1}=$ number of electrical installation and maintenance trade experienced teachers $\quad N_{2}=$ number of electrical installation and maintenance trade inexperienced,$N=$ total number of the respondents

Table 1 presented the data collected from research question 1. The result showed that a total of 14 items were presented to the respondents to indicate the level of ICT integration in teaching Electrical Installation and Maintenance trade in technical colleges in Kano state. The 
respondents considered 11 items as low. The standard deviation also shows a range between 1.21 and 1.49. This indicates that the respondents consider some of the items lower and other items higher. The grand mean of the two groups shows a mean of 2.92, indicating the low level of ICT integration in teaching electrical installation and maintenance work trade. Based on the result presented and the subsequent analysis, the researcher concludes that the participants consider the level of ICT integration in teaching Electrical Installation and Maintenance trade in technical colleges in Kano state low.

The finding from the result presented in study revealed that the level of ICT integration in teaching Electrical Installation and Maintenance trade in Kano State is low. The responses of both electrical installation and maintenance work trade experienced and inexperienced teachers are similar, having the same opinion on 11 out of 14 items. This finding is in agreement with the findings of Musa and Kanya, (2014) which revealed that the ICT integration in teaching and learning was inadequate. It is also in line with the findings of Daniel (2014) who found that the extent of using ICTs in teaching business education was very low. The lack/poor integration of ICT by teachers of Electrical Installation and Maintenance Work Trade posed a challenge for effective teaching/learning of trade course.

\section{Impact of ICT Skills on the Performance of Electrical Installation and Maintenance Work Trade Teachers in Technical Colleges in Kano state}

Table 2: Mean Rating and Standard Deviation of Opinion of the Respondents on the impact of ICT Skills on the Performance of Electrical Installation and Maintenance work trade Teachers

\begin{tabular}{|c|c|c|c|c|c|c|c|c|}
\hline \multirow[t]{2}{*}{$\mathbf{S} / \mathbf{N}$} & \multirow[t]{2}{*}{ Items } & \multicolumn{2}{|c|}{$\mathrm{N}_{1}=26$} & \multicolumn{2}{|c|}{$\mathbf{N}_{2}-31$} & \multirow[b]{2}{*}{$\overline{\boldsymbol{X}}_{\mathrm{G}}$} & \multirow[b]{2}{*}{$\sigma_{G}$} & \multirow[t]{2}{*}{ Remarks } \\
\hline & & $\overline{\boldsymbol{X}}_{1}$ & $\sigma_{1}$ & $\overline{\boldsymbol{X}}_{2}$ & $\sigma_{2}$ & & & \\
\hline & ICT Improve teachers' writing ability & 3.77 & 1.15 & 3.1 & 1.28 & 3.41 & 1.22 & Disagree \\
\hline & ICT Enhance teachers' reading efficiency & 3.85 & 1.23 & 3.1 & 1.15 & 3.44 & 1.19 & Disagree \\
\hline & ICT Improve teachers' listening ability & 3.23 & 1.19 & 3.1 & 1.09 & 3.16 & 1.14 & Disagree \\
\hline & ICT Improved teachers' speaking ability & 3.12 & 1.37 & 3.29 & 1.22 & 3.21 & 1.29 & Disagree \\
\hline & $\begin{array}{l}\text { Use of ICT Minimize teachers' instruction } \\
\text { time }\end{array}$ & 3.23 & 1.45 & 3.87 & 1.04 & 3.58 & 1.23 & Agree \\
\hline & Class control is more effective with ICT & 3.77 & 1.15 & 3.52 & 1.01 & 3.63 & 1.07 & Agree \\
\hline & $\begin{array}{l}\text { Use of ICT enhance teachers' information } \\
\text { search }\end{array}$ & 2.96 & 1.16 & 3.94 & 1.16 & 3.49 & 1.16 & Disagree \\
\hline & $\begin{array}{l}\text { Use of ICT enhance teachers' data } \\
\text { collection and analysis }\end{array}$ & 2.73 & 1.40 & 2.97 & 1.31 & 2.86 & 1.35 & Disagree \\
\hline & $\begin{array}{l}\text { ICT encourage teachers' information } \\
\text { sharing, ideas and other resources among } \\
\text { teachers }\end{array}$ & 3.19 & 1.39 & 3.06 & 1.19 & 3.12 & 1.28 & Disagree \\
\hline & $\begin{array}{l}\text { ICT Improve teachers' lesson plan and } \\
\text { report making }\end{array}$ & 3.5 & 1.12 & 3.81 & 1.09 & 3.67 & 1.10 & Agree \\
\hline & ICT Ease teachers' monitoring and & 3.73 & 1.26 & 3.87 & 1.07 & 3.81 & 1.16 & Agree \\
\hline
\end{tabular}


evaluation of students

ICT Help facilitate teaching-specific concepts or skills

ICT improve teachers' skills of the

Electrical Installation and Maintenance

Work Trade.

ICT improve teachers' information-

handling skills

ICT improve teachers' collaborative and

communication skills

ICT improve teachers' self-learning skills

ICT improve teachers' problem-solving skills

ICT Enhance teachers' class management and control

ICT make teaching easier

ICT help teachers offers effective teaching

ICT improve teachers' quality of teaching

ICT Motivate the teachers

ICT make teachers' feel more professional

ICT enhance teachers' critical thinking, imagination and creativity

ICT enhance teachers' interaction and

collaboration among themselves

ICT improve teachers' deeper understanding of the trade

ICT improve my teaching interest

ICT positively changes the usual

relationship between students in classroom

ICT positively changes the relationship

between the teachers' and the students

ICT stimulate teachers' creativity

ICT positively changes the learning climate in classroom

ICT help teachers' to improve teaching with more updated materials.

Grand Mean $\begin{array}{lllllll}3.5 & 1.31 & 3.84 & 1.11 & 3.68 & 1.20 & \text { Agree }\end{array}$

$\begin{array}{lllllll}3.85 & 1.10 & 3.55 & 1.04 & 3.69 & 1.07 & \text { Agree }\end{array}$

$\begin{array}{lllllll}3.58 & 1.42 & 3.06 & 1.16 & 3.30 & 1.28 & \text { Disagree }\end{array}$

$\begin{array}{lllllll}3.77 & 1.01 & 3.19 & 1.26 & 3.45 & 1.15 & \text { Disagree }\end{array}$

$\begin{array}{lllllll}3.54 & 1.31 & 2.71 & 1.3 & 3.09 & 1.30 & \text { Disagree }\end{array}$

$\begin{array}{lllllll}3.04 & 1.40 & 3.06 & 1.16 & 3.05 & 1.27 & \text { Disagree }\end{array}$

$\begin{array}{lllllll}3.77 & 1.12 & 2.58 & 1.1 & 3.12 & 1.11 & \text { Disagree }\end{array}$

$\begin{array}{lllllll}2.73 & 1.29 & 2.74 & 1.22 & 2.74 & 1.25 & \text { Disagree }\end{array}$

$\begin{array}{lllllll}2.88 & 1.28 & 2.55 & 1.07 & 2.70 & 1.17 & \text { Disagree }\end{array}$

$\begin{array}{lllllll}3.65 & 1.00 & 2.65 & 1.26 & 3.11 & 1.14 & \text { Disagree }\end{array}$

$\begin{array}{lllllll}3.85 & 1.17 & 3.06 & 1.39 & 3.42 & 1.29 & \text { Disagree }\end{array}$

$\begin{array}{lllllll}2.77 & 1.09 & 3.1 & 1.28 & 2.95 & 1.19 & \text { Disagree }\end{array}$

$\begin{array}{lllllll}3.54 & 1.25 & 2.97 & 1.15 & 3.23 & 1.20 & \text { Disagree }\end{array}$

$\begin{array}{lllllll}3.74 & 1.16 & 3.61 & 1.18 & 3.67 & 1.17 & \text { Agree }\end{array}$

$\begin{array}{lllllll}3.88 & 1.05 & 3.65 & 1.15 & 3.75 & 1.10 & \text { Agree }\end{array}$

$\begin{array}{lllllll}3.65 & 1.04 & 3.61 & 1.07 & 3.63 & 1.06 & \text { Agree }\end{array}$

$\begin{array}{lllllll}3.62 & 1.27 & 2.87 & 1.04 & 3.21 & 1.14 & \text { Disagree }\end{array}$

$\begin{array}{lllllll}3.88 & 1.12 & 2.84 & 1.14 & 3.31 & 1.13 & \text { Disagree }\end{array}$

$\begin{array}{lllllll}3.23 & 1.34 & 2.77 & 1.16 & 2.98 & 1.24 & \text { Disagree }\end{array}$

$\begin{array}{lllllll}3.85 & 1.20 & 2.77 & 1.43 & 3.26 & 1.33 & \text { Disagree }\end{array}$

$\begin{array}{lllllll}2.85 & 1.35 & 2.84 & 1.39 & 2.84 & 1.37 & \text { Disagree }\end{array}$

3.30 1.20 Disagree

Key: $\overline{\boldsymbol{X}}_{1}=$ mean response of electrical installation and maintenance trade experienced teachers, $\overline{\boldsymbol{X}}_{2}=$ mean response of electrical installation and maintenance trade inexperienced $\overline{\boldsymbol{X}}_{\boldsymbol{G}}=\boldsymbol{G}$ and of items, $\sigma=$ standard deviation, $N_{l}=$ number of electrical installation and maintenance trade experienced teachers $N_{2}=$ number of electrical installation and maintenance trade inexperienced teachers, $N=$ total number of the respondents 
Research question 2 set out to identify the impact of ICT skills on the performance of Electrical Installation and Maintenance work trade teachers in Technical Colleges in Kano state. Thirty-two (32) items were presented to the respondent. The items received mean responses between 2.70 to 3.81 . The results indicated that out of the 32 items the respondents agree with nine (9) items and disagree with twenty-three (23) items of the research question. The standard deviation also shows that the two groups of respondents have a range of 1.37 and 1.06 and this indicates that, the respondent closely agreed on each of the items. The grand mean of the two groups shows a mean of 3.30. Based on the data presented and the subsequent analysis, the researcher s conclude that the respondents disagreed on the impact of ICT skills on the performance of Electrical Installation and Maintenance work trade teachers in Technical Colleges in Kano state. From the results presented, the respondents agreed that ICT has a negative impact on the performance of electrical installation and maintenance trade teachers. This is in line with the findings of Duhu, Mbaga, Quahha, and Danzaria, (2014) whose findings revealed that teachers were not comfortable with regards to the role of ICT in classroom management/control. Duhu, Mbaga, Quahha, and Danzaria stated that though ICT have been reported by several authors (Anyim, 2018; Basri, Alandejani. \& Almadani, 2018; Saddiquah. \& Salim, 2017; Alakpodia, 2014; Odede \& Enakerakpo, 2014) to have positive impact on teaching and learning but its intergration in the daily teaching and learning in the classroom has always been stampeded by several factors which teachers' competency is a major element.

\section{Hypothesis 1: Significant Difference between the mean responses of Electrical Installation and Maintenance Work Trade Experienced and Inexperienced Teachers on the level of ICT integration in Teaching Electrical Installation and Maintenance Work Trade in Technical Colleges in Kano State.}

Table 3: Z-Test Analysis of Difference between Opinion the Two groups of Respondents

\begin{tabular}{lcccccc}
\hline Respondents & $\mathbf{N}$ & $\overline{\boldsymbol{X}}$ & $\mathbf{S}^{\mathbf{2}}$ & $\mathbf{z}$ - calc & z- crit & Decision \\
\hline Experienced Teachers & 26 & 3.11 & 0.40 & & & \\
$\begin{array}{l}\text { Inexperienced } \\
\text { Teachers }\end{array}$ & 31 & 2.75 & 0.39 & & & \\
\hline
\end{tabular}

Key: N=number of respondents, $\bar{X}=$ mean of the group of respondents, $S^{2}=$ standard deviation of each group, $z$-cal $=$ calculated $z$-value, $z$-crit $=z$-table value

Table 3 revealed that z-cal (3.40) was greater than the z-crit (1.96) at 0.05 level of significance. Therefore, the null hypothesis was rejected indicating that, There is significant difference between the mean responses of electrical installation and maintenance work trade experienced teachers and inexperienced teachers on the level of ICT integration in teaching electrical installation and maintenance work trade in Technical Colleges in Kano state. Based on the data presented in table 3, it was clearly found that, the opinion of Electrical Installation and Maintenance Work Trade experienced and inexperience differed hence the null hypothesis was rejected. This is in line with the findings of Daniel (2014) who found that the extent of using ICTs in teaching business education was very low. The finding is also in agreement with Bakare and Olaniyi (2017) who reported that the level at which people 
perceived a particular phenomenon may be different from one another and as such the difference in the level of ICT integration perceived by the each respondent may not necessarily be the same for all respondents.

\section{Hypothesis Two: Significant Difference between the Mean Responses of Electrical Installation and Maintenance Work Trade Experienced and Inexperienced Teachers on the Impact of ICT Skills on the Performance of Electrical Installation and Maintenance Work Trade Teachers in Technical Colleges in Kano state}

Table 4: Z-Test Analysis of Difference between Opinions of the group of Respondents

\begin{tabular}{lcccccc}
\hline Respondents & $\mathbf{N}$ & $\overline{\boldsymbol{X}}$ & $\mathbf{S}^{2}$ & $\mathbf{z}$ - calc & z- crit & Decision \\
\hline Experienced Teachers & 26 & 3.45 & 0.30 & & & \\
Inexperienced Teachers & 31 & 3.17 & 0.17 & & & \\
\hline
\end{tabular}

Key: $N=$ number of respondents, $\bar{X}=$ mean of the group of respondents, $S^{2}=$ standard deviation of each group, $z$-cal $=$ calculated $z$-value, $z$-crit $=z$-table value

Table 4 revealed that $\mathrm{z}$-cal (4.02) was greater than the z-crit (1.96) at 0.05 level of significance. Therefore, the null hypothesis was accepted indicating that, there was significant difference between the mean responses of electrical installation and maintenance work trade experienced and inexperienced teachers on the impact of ICT skills on the performance of electrical installation and maintenance work trade teachers in technical colleges in Kano state hence the null hypothesis was rejected. The finding is in agreement with Balasubramanian et al, (2019) who in their study suggested that the impact of a given technology is in its adoption and utilization saying that if a technology has not been fully implemented, its essence would not be fully felt by the beneficiaries and as such the need for a full implantation and utilization of ICT for the benefit of the users. The finding was also support by the report of Gidadawa and Dogondaji (2014). Gidadawa and Dogondaji reported that the performance of ICT users will always improve as there are several platforms for the ICT users to improve their skills and possessed inventive and innovative skills.

\section{Conclusion and Suggestion}

Based on the findings of this study, it is concluded that the level of ICT facilities integration in teaching Electrical Installation and Maintenance trade such as interactive whiteboard, internet, chat, and social network, use of ICT to monitor and evaluate students' progress/performance, integration PowerPoint presentation among others in teaching Electrical Installation and Maintenance trade is low as well as negative impact. Based on the findings of the study, it is recommended that Electrical Installation and Maintenance Work Trade Teachers should engage themselves in group discussion and idea-sharing among them on improving ICT integration in teaching electrical installation and maintenance trade. The researchers also suggest that Electrical Installation and Maintenance Work Trade Teachers should be given training through attending seminars and workshop, to improve their ICT skills, so that they could be able to use the facilities in teaching to ease their profession. 


\section{Acknowledgements}

The authors wish to acknowledge with thanks the immeasurable contribution of Dr. D. Moses for giving guidance to the accomplishment of this research work. Profound thanks goes to Prof. I. Tumba and Dr. Kumazhege, S. Z. for finding time to read the manuscript of the work at content and design stages respectively.

\section{Conflict of Interest}

The authors of the article declare no conflict of interest.

\section{Funding}

All associated financial burden for conducting the study and for publishing this article is the responsibility of the authors

\section{References}

Adeosun, O. (2010). Quality basic education development in Nigeria: Imperative for use of ICT. Journal of International Cooperation in Education, 13(2), 193-211.

Aduwa-Ogiegbaen, S. E. \& Iyamu, E. O. (2015). Using information and communication technology in secondary schools in Nigeria: Problems and prospects. Educational Technology \& Society, 8(1), 104-112.

Alakpodia, O. N. (2014). Gender differences in computer use skill among students of school of health technology, Ufuoma, Delta State. International Journal of Digital Library Services,4(4), 1-11.

Alegbemi, F.A (2010). Vocational technology education and work skill requirements in contemporary Nigeria: the way forward in electrical technology education. Proceedings of the Annual National Conference of Nigeria Association of Teachers of Technology Uyo,4(5) 152-161.

Ali, G. Haolader, F. A., \& Muhammad, K. (2013). The role of ICT to make teaching-learning effective in higher institutions of learning in Uganda. International Journal of Innovative Research in Science, Engineering and Technology, 2(8), 61-73

Anyim, W. O. (2018). Assessment of ICT literacy skills of digital library users and staff in Salem University Lokoja. Kogi. Library Philosophy and Practice (e-journal), 1-24

Bakare, A. A. \& Olaniyi, E. T. (2017). Use and Application of ICT in Teaching and Learning for Quality Higher Education in Nigeria. Greener Journal of Educational Research, 7(2), 015-020, http://doi.org/10.15580/GJER.2017.2.020617017

Balasubramanian, K., Clarke-Okah, W., Daniel, J., Ferreira, F., Kanwar, A., Kwan, A. \& West, P. (2019). ICTs for Higher Education. Background paper from the Commonwealth of Learning UNESCO World Conference on Higher Education. UNESCO World Conference on Higher Education Paris, 5 to 8 July 2019. Retrieved from http://unesdoc.unesco.org/images/0018/001832/183207e.pdf

Basil, C. E. et al, (2020). Assessment of ICT skills relevant for effective learning possessed by undergraduate students at University of Nigeria. International Journal of Higher Education, 9(4), 206 - 216

Basri, W. S., Alandejani, J. A. \& Almadani, F. M. (2018). ICT Adoption Impact on Students' Academic Performance: Evidence from Saudi Universities. Education Research International, 1-9. doi:https://doi.org/10.1155/2018/1240197 
Daniel J A. U (2014), Extent of Utilization of Information and Communication Technology in Business Education: Implication for Effective Instructional Delivery Educational Research International, 3(4)

Duhu, P. C. Mbaga, E. V. Quahha, D. W, \& Danzaria, L. (2014). The Perception of electrical engineering trade teachers on the use of information and communication technology for teaching in technical colleges in Adamawa and Gombe states of Nigeria. European Scientific Journal 10(13) 12-21

Gidadawa, Z. S. \& Dogondaji, M. B. (2014) Application of ICT in Nigerian Educational System for Achieving Sustainable Development. International Letters of Social and Humanistic Sciences, 32(2), 62-71

Jung, I. (2015). ICT-Pedagogy integration in teacher training: Application cases worldwide. Educational Technology \& Society, 8(2), 94-101.

Kano state revised education strategic plan (ESP) (2008). Proposal 2009 - 2018. Kano: Kano state printing press

Musa, S. A. \& Kanya, R. A. (2014). Integrating information and communication technology (ICT) to teaching and learning process in Nigeria: The Pros and Cons. Textbook Publication by School of Art and Social Sciences, Sa'adatu Rimi College of Education Kumbotso, Kano, Nigeria 46-51

Odede, I. \& Enakerakpo, E. (2014). ICT skills and internet usage among Library and Information Science students in Delta and Edo States, Nigeria. Internaltional Journal of Librry and Information Scinece, 6(5), 98-107. https://doi.org/10.5897/IJLIS2013.0360

Ohikhiare, T. (2009). Electrical installation and maintenance work. Benin City: P \& P Ventures

Saddiquah, A. \& Salim, Z. (2017). The ICT facilities, skills, usage, and the problems faced by the students of higher education. EURASIA Journal of Mathematics Science and Technology Education, 13(8), 4987-4994. http://dx.doi.org/10.12973/eurasia.2017.00977a

UNESCO, (2017). ICT in Education. United Nation Educational Scientific and cultural Oranization: ParisUNN Statistic Unit (2020). University of Nigeria Statistics. University of Nigeria Nsukka (UNN).

Youssef, A. B. \& Dahmani, M. (2018). The impact of ICT on student performance in higher education: Direct effects, indirect effects and organizational change. RUSC, Universities and Knowledge Society Journal, 5(1), 13.

Yushau, B. \& Nannim, F. A. (2018). ICT facilities and their utilization for educational purposes in Nigeria Universities: A review of literature from 2004 to 2018. ATBU Journal of Science, Technology and Education, 6(1), 237-263 